\title{
Competitive interactions between a nonmycorrhizal invasive plant, Alliaria petiolata, and a suite of mycorrhizal grassland, old field, and forest species
}

Gary T Poon, Hafiz Maherali

The widespread invasion of the nonmycorrhizal biennial plant, Alliaria petiolata in North America is hypothesized to be facilitated by the production of novel biochemical weapons that suppress the growth of mycorrhizal fungi. As a result, $A$. petiolata is expected to be a strong competitor against plant species that rely on mycorrhizal fungi for nutrient uptake services. If $A$. petiolata is also a strong competitor for soil resources, it should deplete nutrients to levels lower than can be tolerated by weaker competitors. Because the negative effect of losing the fungal symbiont for mycorrhizal plants is greatest when nutrients are low, the ability of $A$. petiolata to simultaneously suppress fungi and efficiently take up soil nutrients should further strengthen its competitive ability against mycorrhizal plants. To test this hypothesis, we grew 27 mycorrhizal tree, forb and grass species that are representative of invaded habitats in the absence or presence of competition with $A$. petiolata in soils that had previously been experimentally planted with the invader or left as a control. A history of $A$. petiolata in soil reduced plant available forms of nitrogen by $>50 \%$ and phosphorus by $17 \%$ relative to control soil. Average mycorrhizal colonization of competitor species was reduced by $>50 \%$ in $A$. petiolata history versus control soil.

Contrary to expectations, competition between $A$. petiolata and other species was stronger in control than history soil. The invader suppressed the biomass of $70 \%$ of competitor species in control soil but only $26 \%$ of species in history soil. In addition, $A$. petiolata biomass was reduced by $56 \%$ in history versus control soil, whereas the average biomass of competitor species was reduced by $15 \%$. Thus, our results suggest that the negative effect of nutrient depletion on $A$. petiolata was stronger than the negative effect of suppressing mycorrhizal colonization on competitor species. These findings indicate that the inhibitory potential of $A$. petiolata on competitor species via mycorrhizal suppression is not enhanced under nutrient limitation. 
4 Competitive interactions between a nonmycorrhizal invasive plant, Alliaria petiolata, and a 5 suite of mycorrhizal grassland, old field, and forest species

9 Department of Integrative Biology, University of Guelph, Guelph, ON, N1G 2W1

12 Gary T. Poon and Hafiz Maherali ${ }^{1}$

${ }^{1}$ corresponding author: Hafiz Maherali, Department of Integrative Biology, University of 


\section{Abstract}

The widespread invasion of the nonmycorrhizal biennial plant, Alliaria petiolata in North America is hypothesized to be facilitated by the production of novel biochemical weapons that suppress the growth of mycorrhizal fungi. As a result, A. petiolata is expected to be a strong competitor against plant species that rely on mycorrhizal fungi for nutrient uptake services. If $A$. petiolata is also a strong competitor for soil resources, it should deplete nutrients to levels lower than can be tolerated by weaker competitors. Because the negative effect of losing the fungal symbiont for mycorrhizal plants is greatest when nutrients are low, the ability of $A$. petiolata to simultaneously suppress fungi and efficiently take up soil nutrients should further strengthen its competitive ability against mycorrhizal plants. To test this hypothesis, we grew 27 mycorrhizal tree, forb and grass species that are representative of invaded habitats in the absence or presence of competition with $A$. petiolata in soils that had previously been experimentally planted with the invader or left as a control. A history of $A$. petiolata in soil reduced plant available forms of nitrogen by $>50 \%$ and phosphorus by $17 \%$ relative to control soil. Average mycorrhizal colonization of competitor species was reduced by $>50 \%$ in $A$. petiolata history versus control soil. Contrary to expectations, competition between $A$. petiolata and other species was stronger in control than history soil. The invader suppressed the biomass of $70 \%$ of competitor species in control soil but only $26 \%$ of species in history soil. In addition, $A$. petiolata biomass was reduced by $56 \%$ in history versus control soil, whereas the average biomass of competitor species was reduced by $15 \%$. Thus, our results suggest that the negative effect of nutrient depletion on $A$. petiolata was stronger than the negative effect of suppressing mycorrhizal colonization on competitor species. These findings indicate that the inhibitory potential of $A$. petiolata on competitor species via mycorrhizal suppression is not enhanced under nutrient limitation. 


\section{Introduction}

Invasions by exotic species are common and can negatively influence the structure and function of invaded communities and ecosystems (Pimental et al., 2000). Designing effective control and eradication programs to limit the spread of an invasive species, however, requires identifying the specific mechanism that facilitated invasion (Mack et al., 2000). Numerous mechanisms have been identified to explain successful invasions (Catford et al., 2009; Gurevitch et al., 2011). For example, successful invaders may have high propagule production (Colautti et al., 2006), possess or evolve superior competitive ability for limiting resources (Blossey \& Notzold, 1995), be released from specialist antagonists in their native range (Callaway et al., 2004), possess the ability to acclimate to a wide variety of conditions (Parker et al., 2003), or secrete novel biochemical compounds that reduce the performance and survival of native inhabitants (Callaway \& Ridenour, 2004).

Recent reviews suggest that successful invasions rarely occur because of a single mechanism (Catford et al., 2009; Gurevitch et al., 2011). At least three explanations for weak effects of any one mechanism have been proposed (Gurevitch et al., 2011). First, the efficacy of a particular mechanism may depend on ecological context, where differences in resource availability and the functional attributes of resident species can either facilitate or increase resistance to invasion (Funk et al., 2008). Second, the importance of a particular mechanism could differ between phases of an invasion (Dietz \& Edwards, 2006). For example, allelopathy may effectively suppress resident species in the initial phases of invasion (Callaway \& Ridenour, 2004), but its effects can diminish as resident species acclimate or evolve resistance to the novel biochemicals (Lankau et al., 2009; Lankau, 2011). Third, multiple mechanisms could act synergistically, as observed in situations where invasion is facilitated by both competitive suppression of resident species and reduced palatability to herbivores (Lau \& Schultheis, 2015). Simultaneous empirical assessments of multiple causes of invasion, however, are infrequent (Zheng et al., 2015). 
The widespread invasion of Alliaria petiolata ((M. Bieb.) Cavara \& Grandem, Brassicaceae), a biennial species native to Europe that was introduced to North America in the late $19^{\text {th }}$ century (Cavers et al., 1979), has been attributed to several factors (Rodgers et al., 2008a). Of these mechanisms, the ability of $A$. petiolata to produce allelopathic phytochemicals has received considerable attention. A. petiolata phytochemicals are present in leaf litter and also released as root exudates (Cipollini et al., 2005; Rodgers et al., 2008a), but have limited direct negative effects on neighboring plant species (McCarthy \& Hanson, 1998; Roberts \& Anderson, 2001; Prati \& Bossdorf, 2004; Cipollini et al., 2008). Instead, A. petiolata phytochemicals tend to suppress the growth of mycorrhizal fungi (Roberts \& Anderson, 2001; Stinson et al., 2006; Callaway et al., 2008; Rodgers et al., 2008a; Wolfe et al., 2008; Cantor et al., 2011), though the effect is variable (Burke, 2008; Lankau et al., 2009; Lankau, 2011). Because A. petiolata is nonmycorrhizal, whereas most plant species rely on mycorrhiza for nutrient uptake services (Wang \& Qiu, 2006; Brundrett, 2009), the suppression of mycorrhizal fungi is expected to advantage $A$. petiolata relative to other species during establishment (Stinson et al., 2006; Callaway et al., 2008; Hale \& Kalisz, 2012), though this effect can diminish over time (Lankau et al., 2009; Lankau, 2011).

The successful establishment and persistence of $A$. petiolata may also be influenced by the joint effects of novel biochemical weapons and the ability to acquire soil resources more effectively than potential competitors (Blossey \& Notzold, 1995). Resource competition theory predicts that the strong competitors deplete limiting resources to levels lower than weaker competitors (Tilman, 1988; Tilman \& Wedin, 1991; Bever et al., 2010). If $A$. petiolata is a strong resource competitor, it should deplete soil nutrients below tolerable limits for other species, suppressing other species more than itself. The ability to efficiently take up nutrients as well as survive and reproduce under limited soil nutrients could explain A. petiolata's ability to colonize habitats that vary widely in nutrient availability (Rodgers et al., 2008b) as well its ability to suppress native vegetation (e.g., Stinson et al., 2007; Rodgers et al., 2008a). Moreover, if $A$. petiolata can suppress mycorrhizal fungi while simultaneously depleting soil nutrients, this 
should result in even stronger suppression of mycorrhizal competitors. This is because the negative effect of losing the fungal symbiont is greatest when mycorrhizal plants are grown in low soil nutrients (Hoeksema et al., 2010; Johnson, 2010).

Despite the potential for $A$. petiolata to modify the soil environment in a way that enhances its own competitive ability, resident species may still be able to resist invasion. Such resistance could depend on the morphological and physiological traits that influence acquisition of soil nutrients and light, which most often limit plant growth (Grime, 1977; Gaudet \& Keddy, 1988; Goldberg \& Landa, 1991; Wardle et al., 1998; Funk et al., 2008). The potential for depletion of soil nutrients and the suppression of mycorrhizal fungi by $A$. petiolata suggests that resident species which resist competitive suppression should have thin roots that maximize absorptive root surface area for resource uptake (Goldberg, 1996; Casper \& Jackson, 1997). In addition, species that successfully resist invasion by $A$. petiolata could also be effective at acquiring light (Stinson \& Seidler, 2014), particularly by accelerated height growth, which would allow them to overtop neighbors, and by having high photosynthetic light use efficiency (Gaudet \& Keddy, 1988; Goldberg \& Landa, 1991; Rosch et al., 1997; Keddy et al., 2002; Wang et al., 2010). The competitive ability of $A$. petiolata against other species has been tested in pairwise competition trials (Meekins \& McCarthy, 1999; Rodgers et al., 2008a; Lankau, 2010; Leicht-Young et al., 2012), but whether growth in previously invaded soils enhances its competitive ability against mycorrhizal plant species is not known (Hale \& Kalisz, 2012; Smith \& Reynolds, 2014).

To test the hypothesis that nutrient depletion in the first year of an invasion enhances the competitive ability of $A$. petiolata against resident mycorrhizal plant species in subsequent years, we grew $A$. petiolata with and without multiple competitor species in forest soil that had either been left intact or previously planted with $A$. petiolata. This latter treatment simulates a reduction in soil nutrient availability because $A$. petiolata is expected to take up resources during growth. However, the experiment does not strictly mimic the entire process of invasion in the field because the high decomposability of $A$. petiolata leaves is expected to return nutrients to soil in 
126 the longer term (e.g., Rodgers et al., 2008b). The experimental design nonetheless allows us to

127 address whether the competitive ability of $A$. petiolata can be influenced by changes in overall

128 resource availability. Because $A$. petiolata occurs in a wide variety of habitats, including old

129 fields, road sides, forest edges and forest understories (Cavers et al., 1979; Stinson \& Seidler,

130 2014; Smith \& Reynolds, 2014; Biswas et al., 2015), we quantified competition between $A$.

131 petiolata and 27 native and non-native mycorrhizal competitor species that represent these

132 different habitats (e.g., Cavers et al., 1979). We predicted that soil nutrient reduction and the

133 potential for inhibition of mycorrhizal fungi by previous growth of A. petiolata in soil ('history

134 soil') inhibits the growth of mycorrhizal plant species. As a result, A. petiolata should more

135 strongly suppress the growth of, and resist growth suppression by, competitor species in the

136 history soil treatment than in control soil. We predicted that competitor species with finer roots,

137 greater height extension, and higher photosynthetic efficiency would be more likely to resist

138 competition against $A$. petiolata.

140 Materials and Methods

141 To examine competitive interactions between resident species and $A$. petiolata, we grew 27

142 target species with and without the presence of $A$. petiolata (Table 1). Competitor species

143 included forest trees, forest understory herbs, old field herbs and grasses that are commonly

144 found in areas typically invaded by A. petiolata in southern Ontario (e.g., Biswas et al., 2015).

145 Alliaria petiolata seeds were bulk collected from the Wild Goose Woods, a mixed hardwood

146 forest in the University of Guelph Arboretum $\left(43^{\circ} 32^{\prime} \mathrm{N}, 80^{\circ} 12^{\prime} \mathrm{W}\right)$ in July 2009. Alliaria

147 petiolata can be found in dense patches along the periphery of the forest throughout this site.

148 Seeds for each competitor species were harvested within the Guelph Arboretum as well as

149 purchased from suppliers [Acorus Restoration, Walsingham, ON; Angelgrove Seed Company,

150 Harbour Grace, NL, Ontario Tree Seed Facility, Angus, ON; Richter's Herbs, Goodwood, ON

151 (Table 1)]. 
152

153

154

155

156

157

158

159

160

161

162

163

164

165

166

167

168

169

170

171

172

173

174

175

176

177

178

To simulate a soil environment that $A$. petiolata is likely to encounter upon invasion, we grew plants in a forest soil without a history of $A$. petiolata. In November 2009, soil was collected to a depth of $30 \mathrm{~cm}$ from a mixed deciduous forest dominated by Acer saccharum in

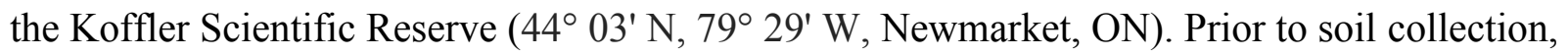
live aboveground vegetation and macro-organic matter (leaves and twigs) were removed. Soil was sieved onsite to remove roots and stones and placed into $30,35 \mathrm{~L}$ tubs $(60.7 \mathrm{~cm}$ long $\times 40.4$ cm wide $\times 22.1$ cm deep; Roughneck Storage Box \#2214, Newell Rubbermaid Inc, Atlanta, GA). Tubs had holes drilled in the bottom to facilitate drainage. Soils were stored at $4{ }^{\circ} \mathrm{C}$ prior to the beginning of experiments. To experimentally create a treatment where the presence of $A$. petiolata has modified the soil, we grew A. petiolata plants in half of the field collected soil (e.g., Callaway et al., 2008). The remaining soil was left intact in the tubs. To create the $A$. petiolata soil history treatment, $A$. petiolata seeds were cold stratified at $4^{\circ} \mathrm{C}$ for 120 days on moist filter paper placed inside $10 \mathrm{~cm}$ diameter parafilm sealed petri dishes. In January 2010, 100 germinating $A$. petiolata seeds were transplanted into each of 15 randomly selected tubs. After 6 weeks, seedlings were thinned to a density of 80 plants $/ \mathrm{m}^{2}$, which approximates the upper end of A. petiolata density in field populations (Meekins \& McCarthy, 2002). Tubs containing $A$. petiolata seedlings and those containing intact control soil were randomly arranged on the greenhouse bench and watered to maintain field capacity. Germinating seedlings from other species were periodically removed from all tubs. Alliaria petiolata plants were harvested 5 months after germination to simulate the approximate active growing season for first year rosettes of this species in southern Ontario and to allow roots to fully explore the soil in the tubs. At harvest, the aboveground portion of plants was removed and discarded, and soil was sieved to remove roots and homogenized within each soil treatment.

To quantify the effect of $A$. petiolata history on soil nutrients, we sampled $500 \mathrm{~mL}$ of soil from the post-harvest homogenized soil mixture for each treatment and analyzed it for plant available nutrients, including $\mathrm{NO}_{3}{ }^{-}, \mathrm{NH}_{4}{ }^{+}, \mathrm{P}$ (Olsen), $\mathrm{Mg}$, and $\mathrm{K}$ in mg per unit mass $(\mathrm{kg})$ or volume (L) of soil (University of Guelph Laboratory Services; 
179 www.guelphlabservices.com/AFL/plants.aspx). Soil that had been left without A. petiolata 180 contained $160 \mathrm{mg} / \mathrm{kg} \mathrm{NO}_{3}{ }^{-}, 18.3 \mathrm{mg} / \mathrm{kg} \mathrm{NH}{ }^{+}, 23 \mathrm{mg} / \mathrm{L} \mathrm{P}, 77 \mathrm{mg} / \mathrm{L} \mathrm{Mg}$, and $52 \mathrm{mg} / \mathrm{L} \mathrm{K}$. In soil 181 with $A$. petiolata history, these amounts were reduced to $29.2 \mathrm{mg} / \mathrm{kg}$ for $\mathrm{NO}_{3}^{-}(-82 \%$ decrease), $1828.56 \mathrm{mg} / \mathrm{kg}$ for $\mathrm{NH}_{4}{ }^{+}(-53 \%$ decrease), $19 \mathrm{mg} / \mathrm{L}$ for P $(-17 \%$ decrease $), 53 \mathrm{mg} / \mathrm{L}$ for $\mathrm{Mg}(-31 \%$ 183 decrease) and $40 \mathrm{mg} / \mathrm{L}$ for K (-23\% decrease).

To study the effects of soil treatment, interspecific competition and competitive species

185 identity on the growth of either $A$. petiolata or the competitor, we used a three-factor design. To quantify competition, we grew each competitor species in the presence and absence of an $A$. petiolata individual in the same pot (e.g., Gaudet \& Keddy, 1988; Wang et al., 2010) in both soil treatments. We also grew A. petiolata alone as a reference to calculate its response to competition with the other species. Each treatment combination $[(27$ species + A. petiolata $) \times 2$ soil treatments $\times 2$ competition treatments] was replicated 6 times for a total of 744 pots. Pots (650 mL volume, $6.4 \mathrm{~cm}$ wide $\times 25 \mathrm{~cm}$ deep; D40 R, Stuewe and Sons Inc., Tangent, OR) were filled with either $A$. petiolata history or untreated field soil and were randomly arranged in a checkerboard pattern across 53 trays (57 N25T, Stuewe and Sons, Inc., Tangent, OR) to minimize competition for light between pots. To induce germination, all seeds were cold stratified for 30-120 days based on information provided by seed suppliers. Cold stratification times were staggered to ensure all species germinated at the same time. After stratification, seeds were moved to the University of Guelph Phytotron greenhouse and germinated in a medium of $2 / 3$ top soil and $1 / 3$ silica sand and then transplanted into experimental treatments. Because of slow germination in some species, they were planted in two groups separated by two weeks. All plants were grown for the same number of days and were completely randomized across the greenhouse benches. $100 \mathrm{~mL}$ of $1 / 4$ strength 18-9-18 N:P:K fertilizer (Plant Products, Leamington, $\mathrm{ON}$ ) was added once to all pots in both soil treatments to promote seedling establishment. Because an equal amount of fertilizer was added to all pots, nutrient differences between the $A$. petiolata history and control soil treatments remained. After 63 days, when 
205 herbaceous competitor plants had reached reproductive maturity, the aboveground parts of plants

206 were harvested, separated according to species, dried at $60^{\circ} \mathrm{C}$ for 48 hours and weighed.

207 To determine if $A$. petiolata soil history suppressed arbuscular mycorrhizal (AM) fungi,

208 we harvested the roots of a subset of competitor species when grown alone in both history and

209 control soil. To quantify root colonization by AM fungi, we selected eight species that

210 represented the range of growth forms in the experiment. Root cell contents were cleared with

211 potassium hydroxide and AM fungi were stained with Chlorazol black E (Brundrett et al., 1984).

212 Samples were mounted on glass slides and viewed under a compound microscope at $250 \times$

213 magnification. To quantify fungal colonization by AM hyphae, arbuscules, and vesicles, we used

214 the gridline intersection method (McGonigle et al., 1990). Colonization was quantified as the

215 presence or absence of well-stained structures at 50 intersections per root sample.

216 To determine whether morphological and physiological traits could explain the ability of

217 competitive species to either resist suppression by, or suppress $A$. petiolata, we measured

218 aboveground traits on all plant species in the absence of competition in both soil treatments. We

219 measured leaf chlorophyll concentration and photosynthetic efficiency of up to 6 individuals

220 from each species in each soil treatment at 5 and 9 weeks growth. Height at 5 weeks on these

221 individuals was recorded as the vertical distance from the soil surface to the tip of the tallest leaf.

222 We measured chlorophyll concentration on the three youngest fully expanded leaves per plant

223 using a portable chlorophyll meter (SPAD 502, Minolta, Inc., Ramsey, NJ), and calculated an

224 average value per plant. We measured photosynthetic efficiency as instantaneous fluorescence

225 yield under saturating light conditions $\left(1500 \mu \mathrm{mol} \mathrm{m}^{-2} \mathrm{~s}^{-1}\right)$, a measure of the light use efficiency

226 of photosystem II (Maxwell \& Johnson, 2000). The three youngest fully expanded leaves per

227 plant were measured using a light-adapted fluorometer (PAM-2500, Heinz Walz APbH,

228 Effeltrich, Germany) and an average value per plant was calculated.

229 To determine if root traits co-varied with competitive ability, we grew 5 replicates of all

230 plant species in a separate experiment in a sterilized mixture of $2 / 3$ silica sand and $1 / 3$ topsoil for

23135 days. Root architecture could not be measured in the main experiment because roots could not 
232 be effectively separated from the higher organic matter containing field soil, and because roots

233 were becoming pot bound by the time of harvest. The shorter growing period and silica sand-

234 topsoil mixture prevented plant roots from becoming pot bound and facilitated the harvest of

235 intact root systems. Plants were grown individually in $650 \mathrm{~mL}$ pots (D40 R, Stuewe and Sons

236 Inc., Tangent, Oregon, USA). At harvest, roots were cleaned and preserved in 50\% ethanol. For

237 analysis, roots were stained with $0.05 \%$ Toluidine Blue $\mathrm{O}$ to improve the visibility of fine roots,

238 spread out in water to minimize overlap and photographed with a high resolution (6400 dpi)

239 scanner (Epson V700, Epson Canada Limited, Markham, ON). Root images were analyzed with

240 WinRhizo software (version 2009a; Regent Instruments 2009, Quebec City, QC) using the

241 automatic pixel classification setting to assess the length and average root diameter of each root

242 system. After scanning, roots were dried at $60^{\circ} \mathrm{C}$ for 48 hours and weighed. In addition to

243 average root diameter, we also calculated specific root length (SRL), or the ratio of root length to

244 root mass, which is indicative of the amount of surface area available for nutrient absorption

245 (Craine et al., 2001).

246 To assess the magnitude and variation in resistance of competitor species to $A$. petiolata

247 competition and whether the magnitude of resistance is influenced by A. petiolata soil history,

248 we analyzed aboveground biomass of competitor species with a three-way analysis of variance

249 (ANOVA) with competition, soil history and competitor species identity and all interactions as

250 factors. Planned orthogonal single degree of freedom (1-df) contrasts were used to determine

251 whether each competitor species biomass differed between competition treatments within each

252 soil history treatment. We also used 1-df contrasts to test whether growth forms (trees, forbs,

253 grasses) differed as a whole between competition treatments in each soil history treatment.

254 To assess the magnitude and variation in the ability of competitor species to influence $A$.

255 petiolata aboveground biomass, and whether this species effect was influenced by soil history,

256 we used a two-way ANOVA with competitor species identity, soil history and their interaction as

257 factors. To test whether growth with a competitor species suppressed the biomass of $A$. petiolata

258 in each soil treatment, we used planned orthogonal 1-df contrasts to compare the biomass of $A$. 
259

260

261

262

263

264

265

266

267

268

269

270

271

272

273

274

275

276

277

278

279

280

281

282

283

284

285

petiolata grown alone relative to its growth i) with each competitor, ii) with each growth form in aggregate, and iii) across all competitor species in aggregate. The effect of soil treatment on fungal colonization of roots was determined with a two-way ANOVA with soil and species as factors. The statistical significance of soil treatment on fungal colonization for each species was determined by comparing $95 \%$ confidence intervals for overlap. The effect of growth form and soil treatment on plant traits was tested with a two-way ANOVA using species means for each trait as the replicate. Differences among growth forms were determined by comparing the $95 \%$ confidence intervals for each growth form for overlap following a significant main effect. All ANOVAs and 1-df contrasts were done with SPSS 22.0 (IBM Corp., Armonk, NY).

To quantify variation in the ability of competitor species to either resist suppression by $A$. petiolata or suppress A. petiolata, we calculated two indices of competition. The ability of a competitor species to resist suppression is defined as competitive response (CR, Wang et al., 2010), and was quantified as $\ln$ (biomass under competition/biomass alone). The ability of each competitor species to suppress $A$. petiolata is defined as competitive effect (CE, Gaudet \& Keddy, 1988; Wang et al., 2010), and was quantified as $-\ln ($ A. petiolata biomass under competition/A. petiolata biomass alone). When calculated this way, greater values reflect stronger competitive ability.

To determine whether morphological and physiological traits of competitor plants were associated with competitive ability, we used phylogenetic generalized least squares (PGLS) multiple regression, with competitive ability (either $\mathrm{CR}$ or $\mathrm{CE}$ ) as the dependent variable and traits as independent variables. Growth form of plants was used as a covariate in the analysis. Because root traits were assessed in a different experiment, multiple regression analyses were run separately for aboveground and belowground traits. To analyze data, we used the time calibrated phylogenetic tree from Davies et al. (2004) in Phylomatic (Webb et al., 2008), pruned to include the competitor species. In PGLS regression, the phylogenetic variance-covariance matrix is incorporated into the calculation of coefficients $(\beta)$ for either a univariate or multiple regression model (Martins \& Hansen, 1997; Pagel, 1999). To calculate the magnitude of 
phylogenetic effects on the regression, maximum likelihood is used to estimate $\lambda$, an index which varies from 0 , indicating complete independence between variation in the regression residuals and phylogeny, and 1, indicating complete dependence between residual variation with Brownian model of evolution (Freckleton et al., 2002). When $\lambda=0$, the PGLS regression is identical to ordinary least squares regression. PGLS regression and estimates of $\lambda$ were done in R version 3.12 (R Core Team, 2015) using the 'pgls' command in the package caper, version 0.5.2 (Orme et al., 2013).

\section{Results}

The average aboveground biomass of competitor species was reduced by the presence of A. petiolata compared to when they were grown alone (significant competition main effect, Table 2). However, competition was weaker in soil with a history of $A$. petiolata relative to control soil (significant soil history $\times$ competition interaction, Table 2, Fig. 1). The average biomass of competitor species was reduced by $59 \%$ in control soil compared to $27 \%$ in $A$. petiolata history soil. The influence of soil history on competition also varied among species (significant species $\times$ soil history $\times$ competition interaction, Table 2, Fig.1). For example, the aboveground biomass of 19 species (70\%; 13/18 native, 6/9 introduced) was suppressed by competition in control soil whereas only 7 species $(26 \% ; 4 / 18$ native, $3 / 9$ introduced) were suppressed by competition in $A$. petiolata history soil. On a growth form basis, trees $(-38 \%, P=$ $0.01)$, forbs $(-62 \%, P<0.000001)$ and grasses $(-56 \%, P<0.000001)$ were all suppressed by $A$. petiolata in control soil, whereas the biomass of forbs $(-32 \%, P<0.000001)$ and grasses $(-14 \%$, $P=0.007)$, but not trees $(P=0.228)$, was significantly reduced by competition in the $A$. petiolata history soil (Fig.1, insets).

The average biomass of $A$. petiolata in competition was not significantly different from its average biomass when grown alone in either soil treatment $\left(P_{\text {history }}=0.284, P_{\text {control }}=0.602\right.$; Fig. 2). Alliaria petiolata biomass varied in response to competition with different competitor species (significant species effect, Table 3, Fig. 2). In most cases, these species effects were not 
313 consistent between control and history soils (significant species $\times$ soil history interaction, Table

$3143)$. For example, relative to its biomass when alone, $A$. petiolata was significantly smaller in

315 competition with $H$. matronalis, B. inermis, E. canadensis, E. riparius, and E. virginicus in

316 control soil but significantly smaller in competition with Q. macrocarpa, H. matronalis and E.

317 canadensis in history soil (Fig. 2). In some cases, A. petiolata biomass was higher when grown

318 with a competitor species than when grown alone. This response occurred with $P$. strobus and T.

319 occidentalis in control soil and H. perforatum in history soil. A. petiolata biomass response to

320 competition also varied with growth form, and this effect differed between soil treatments (Fig.

3212 , insets). In control soil, $A$. petiolata biomass was $27 \%$ higher $(P=0.041)$ when grown with

322 trees than when grown alone, $43 \%$ lower $(P=0.001)$ when grown with grasses than when grown

323 alone, and not influenced by forbs $(P=0.61)$. In history soil, $A$. petiolata biomass was not

324 affected by competition with trees $(P=0.96)$ or forbs $(P=0.38)$, but was $62 \%$ lower $(P=0.033)$

325 when grown with grasses than when grown alone.

326 On average, competitor species grown alone in soil with a history of $A$. petiolata were

$32715 \%$ smaller than plants grown in control soil $\left(\mathrm{F}_{1,261}=21.991, P=0.000004\right.$, Fig. 3). Competitor

328 species also differed in their response to $A$. petiolata soil history $\left(\mathrm{F}_{26,261}=3.042, P=0.000003\right)$,

329 though a majority showed no significant difference between treatments. Significant negative

330 effects of soil history were found for $Q$. macrocarpa $(-37 \%, P=0.041), H$. matronalis $(-29 \%, P$

$331=0.041), R$. hirta $(-43 \%, P<0.000001)$, E. riparius $(-20 \%, P=0.048)$, and $P$. virgatum $(-33 \%$,

$332 P<0.000001)$. The strongest negative response to soil history was observed for $A$. petiolata,

333 whose biomass was $56 \%$ lower in soil in which it had been previously planted than in control

334 soil $(P=0.004)$.

335 Plants grown in soils with a history of $A$. petiolata had reduced levels of arbuscular

336 mycorrhizal colonization of roots (Fig. 4). On average, plants in the soil history treatment had

$33757 \%$ reduced hyphal colonization $\left(\mathrm{F}_{1,60}=20.47, P=0.000029\right), 53 \%$ reduced arbuscular

338 colonization $\left(\mathrm{F}_{1,60}=4.97, P=0.029\right)$, and $57 \%$ reduced vesicular colonization $\left(\mathrm{F}_{1,60}=4.95, P=\right.$

339 0.030) than plants grown in control soils. These effects were strongest in $Q$. macrocarpa, $F$. 
340 virginiana and E. canadensis for hyphae (Fig. 4a), H. perforatum for arbuscles (Fig. 4b) and $F$.

341 virginiana for vesicles (Fig 4c). We note that Q. macrocarpa is not typically colonized by AM

342 fungi (Table 1), and so the levels of fungal colonization reported for this species may reflect a

343 non-functional symbiosis. The average sizes of the soil history effect on colonization with $Q$.

344 macrocarpa removed from the dataset were $-53 \%$ for hyphae $\left(\mathrm{F}_{1,51}=14.7, P=0.000353\right)$, -

$34552.5 \%$ for arbuscles $\left(\mathrm{F}_{1,51}=4.63, P=0.036\right)$ and $-54.5 \%$ for vesicles $\left(\mathrm{F}_{1,51}=3.38, P=0.072\right)$,

346 Morphological and physiological traits of competitor plants grown alone differed among

347 growth forms, but were not generally affected by growing in soil with a history of $A$. petiolata

348 (Fig. 5). Quantum yield of photosystem II [Y(II)] measured at week 5 was significantly higher in

349 herbs and grasses relative to trees. In week 9, Y(II) was significantly higher in herbs compared to

350 grasses and trees (Fig 5a). The quantum yield of photosystem II did not differ between soil

351 treatments in week 5, but was lower in A. petiolata history soil than control soil in week 9.

352 Chlorophyll concentration in week 5 was significantly higher in herbs and grasses than trees, but

353 did not differ among growth forms in week 9, and did not differ between soil history treatments

354 (Fig. 5b). At week 5, grasses were significantly taller than trees and herbs, but height was not

355 influenced by soil history treatment (Fig. 5c). Trees had significantly larger root diameter than

356 either herbs or grasses, which did not differ significantly from each other. Trees also had

357 significantly lower SRL than herbs, whereas grasses had intermediate SRL that did not differ

358 significantly from that of trees or herbs (Fig. 5d \& 5e).

359 Though above and belowground functional traits varied among growth forms, these traits

360 were generally not associated with their ability to compete in either soil environment, measured

361 as either the ability to resist suppression from (competitive response, CR) or suppress

362 (competitive effect, CE) A. petiolata (Table 4). The only exception to this pattern was the nearly 363 significant $(P=0.06)$ positive relationship between Y(II) @ 5 weeks and competitive response in 364 A. petiolata history soil. In addition, even though species varied in their response to soil history, 365 this variation was also not correlated with competitive ability. The $\ln$ response ratio of growth in 366 A. petiolata history versus control soils (Fig. 3) was not associated with either competitive 
367

368

response $\left(\mathrm{F}_{1,25}=0.07, \mathrm{r}^{2}=0.003, P=0.79, \lambda=0.978\right)$ or competitive effect $\left(\mathrm{F}_{1,25}=0.57, \mathrm{r}^{2}=\right.$ $0.022, P=0.45, \lambda=0.266)$.

Metrics of competitive ability were not strongly correlated across soil treatments.

Specifically, CR in control soil only explained $5.7 \%$ of the variation in CR in A. petiolata history soil, and CE in control soil only explained $12 \%$ of the variation in CE in history soil (Fig. 6). CR and $\mathrm{CE}$ were positively correlated in control soil $\left(\mathrm{F}_{1,25}=7.44, \mathrm{r}^{2}=0.229, P=0.01, \lambda=1\right)$, but were not correlated with each other in history soil $\left(\mathrm{F}_{1,25}=2.73, \mathrm{r}^{2}=0.098, P=0.11, \lambda=0\right)$.

\section{Discussion}

Our results indicate that $A$. petiolata is a strong competitor against a range of common mycorrhizal grassland, old field and forest species in soils which had no previous history with its conspecifics, but contrary to expectation, this competitive advantage weakens in soil with a history of conspecific growth. In uninvaded control soil, for example, A. petiolata suppressed the biomass of a majority of competitor plant species by an average effect size that exceeded $50 \%$ (Fig. 1). By contrast, the suppression of competitor species' biomass by A. petiolata was weaker in history soil, with an effect size that was less than half of that observed in control soil. Moreover, $70 \%$ of species responded negatively to the presence of $A$. petiolata in control soil, but only $26 \%$ of species responded negatively in conspecific history soil. Because the soil history treatment reduced plant available nutrients in soil and reduced mycorrhizal colonization of roots, differences in $A$. petiolata competitive ability between treatments could be caused by these factors acting independently or in combination. Nevertheless, our findings suggest that the competitive ability of newly introduced $A$. petiolata is sufficient to displace competitor species in previously uninvaded sites in the short term, but modification of the soil environment by $A$. petiolata may not enhance its competitive ability.

The weaker competitive effect of $A$. petiolata on other species in history soil occurred despite suppression of mycorrhizal fungi. Mycorrhizal colonization in soils with $A$. petiolata history (Fig. 4) was reduced by levels comparable to that observed in the field (e.g., Barto et al., 
394 2011), with concomitant reductions in competitor plant growth (Fig. 3). However, competitor

395 species were still better able to resist competition from $A$. petiolata in soils with a history of the

396 invader than control soils. Though we cannot separate the individual effects of nutrient depletion

397 and reduced mycorrhizal colonization on the outcome of competition in the present study, we

398 note that $A$. petiolata was suppressed in the soil history treatment at a level that was more than

399 three times the average level of suppression across all competitor species (Fig. 3). Because $A$.

400 petiolata is nonmycorrhizal, the strong negative effect of growth in conspecific soil on its

401 biomass was most likely caused by lower nutrients. We suggest, therefore, that the most likely

402 explanation for weaker competitive ability of $A$. petiolata in history soils is that the negative

403 effect of nutrient depletion on $A$. petiolata was stronger than the negative effect of suppressing

404 mycorrhizal colonization on competitor species. Davis et al. (2012) also observed weak effects

405 of $A$. petiolata soil history on the biomass of competitor species. The observation that

406 competition was weaker overall in history soil is also consistent with the hypothesis that when

407 plant growth is suppressed by environmental stress or low fertility, limited overall demand for

408 resource uptake reduces the strength of competition (Grime 1977; Lamb et al. 2007).

409 Our findings imply that the negative effect of $A$. petiolata on mycorrhizal fungi as a

410 mechanism of competition during invasion may be weaker than previously expected. Though

411 this interpretation is supported by weaker competition in the A. petiolata history soil, where

412 colonization of roots by AM fungi was reduced, it is tentative for two reasons. First, we did not

413 quantify AM fungal colonization of roots for all competitor species, and it is possible that these

414 effects were not the same in unmeasured species. Second, though the reduction in AM fungal

415 colonization of roots is consistent with the presence of fungal inhibiting secondary chemicals

416 produced by $A$. petiolata, we did not directly quantify the concentration of these compounds in

417 A. petiolata history soil. Though secondary chemicals produced by A. petiolata likely reduced

418 fungal populations during the 5 month soil conditioning period (Roberts \& Anderson, 2001;

419 Stinson et al., 2006), they may have been absent in the main experiment because of a short half-

420 life (Barto \& Cipollini, 2009). 
We hypothesized that $A$. petiolata's strong competitive ability is caused by the capacity

422 to deplete limiting resources to levels lower than resident species, as expected from resource 423 competition theory (Tilman, 1988; Tilman \& Wedin, 1991; Bever et al., 2010). However, 424 simulated nutrient depletion of soils by $A$. petiolata more strongly suppressed its own growth 425 relative to competitor species. The ability of $A$. petiolata to suppress other species may therefore 426 be caused by other traits, such as fast growth rate and high allocation to leaf area (Grime, 1977;

427 Funk et al., 2008; Engelhardt \& Anderson, 2011). The tendency for decomposing A. petiolata 428 leaf litter to increase soil nutrient availability in the years following successful invasion (Rodgers 429 et al., 2008b) also suggests that this species has evolved to compete effectively at high, rather 430 than low, soil resources. In addition, we note that our experiment simulates competition between 431 first year individuals of $A$. petiolata and competitor species. In the field, competition also takes 432 place between spring flowering $A$. petiolata plants that have over wintered as rosettes and newly 433 germinating plants of competitor species, which can further advantage A. petiolata (Herold et al., 434 2011). The observation that nutrient depletion caused by conspecifics reduces individual plant 435 performance, however, corroborates previous findings that $A$. petiolata experiences relatively 436 strong intra-specific competition (Meekins \& McCarthy, 1999; Davis et al., 2012; Leicht-Young 437 et al., 2012), which would limit the net reproductive rate of established populations. The 438 possibility of nutrient-limitation mediated density-dependent population regulation is consistent 439 with recent demographic analyses showing that in situations where other biotic factors such as 440 herbivory are excluded, established $A$. petiolata populations decline towards extinction (Knight 441 et al., 2009; Kalisz et al., 2014).

Growth form was the best predictor of the ability of competitor species to either resist or suppress $A$. petiolata, but this effect varied with soil history and competition metric. For example, A. petiolata suppressed the growth of all three growth forms in control soil, but this effect was more modest in A. petiolata history soil. By contrast, grasses suppressed invader

446 biomass in both soil treatments, whereas forbs had no effect, and trees appeared to facilitate the 447 growth of $A$. petiolata in control soils. The ability of grasses to suppress $A$. petiolata may have 
448 occurred because they were taller than other growth forms at a young age, which would increase

449 light acquisition (Grime 1977; Gaudet \& Keddy, 1988; Goldberg \& Landa, 1991; Rosch et al.,

450 1997; Keddy et al. 2002; Wang et al. 2010). Grasses also had relatively fine roots (Fig. 5), which

451 would increase nutrient uptake capacity (Aerts et al., 1991; Goldberg, 1996; Casper \& Jackson,

452 1997). Nonetheless, height may be the most important factor because grasses and forbs had

453 similar photosynthetic capacity and root architecture, yet forbs did not suppress $A$. petiolata

454 biomass. Meekins and McCarthy (1999) also found that $A$. petiolata was a weaker competitor

455 against tall relative to short species. Though the ability of $A$. petiolata to suppress tree growth

456 has been previously observed (Stinson et al., 2007), the observation that trees might facilitate $A$.

457 petiolata growth was unexpected. This effect may be due to aspects that were unique to the two

458 tree species, $P$. strobus and T. occidentalis, which had the strongest beneficial effect on $A$.

459 petiolata. These species were the only conifers in the sample and also ranked lowest in terms of

460 growth rate (Fig 1). The relatively strong growth form effects of competitor species on $A$.

461 petiolata we report here may not be universal however. Other studies suggest that trees can be

462 strong competitors (Meekins \& McCarthy, 1999; Smith \& Reynolds, 2014) and grasses can be

463 weak competitors (Smith \& Reynolds, 2014) against $A$. petiolata.

464 Functional trait variation, beyond that associated with growth form, did not predict either

465 the ability of competitor species to resist suppression by, or their ability to suppress, A. petiolata.

466 When growth form was included in multiple regressions between traits and competitive response

467 or competitive effect, no significant relationships were found, regardless of soil treatment (Table

468 4). There was also limited trait plasticity in response to A. petiolata history in soil (Fig. 5),

469 despite strong effects on plant biomass. These findings are consistent with those of Wang et al.

470 (2010), who also reported weak relationships between trait values and competitive ability. The

471 inability to detect specific relationships between traits and competitive ability could be caused by

472 the possibility that competitive ability depends on combinations of several traits or traits that

473 were not measured (Wardle et al., 1998; Wang et al., 2010), or because functionally alternate 
474 strategies, such as efficient resource acquisition or resource storage, can result in similar 475 competitive abilities (Grime, 1977).

476 Our findings have implications for recent hypotheses about how competitive response 477 and competitive effect should be correlated across environments (Keddy et al., 1994; Keddy et 478 al., 2002; Wang et al., 2010). Specifically, competitive response is expected to be context 479 specific, varying with resource availability or other ecological and environmental factors, and is 480 not expected to be correlated across environments. By contrast, competitive effect is expected to 481 be a general property of a species, such that it is positively correlated across environments 482 (Wang et al., 2010). Our results are generally consistent with these predictions (Fig. 6), but the 483 relationship between competitive effect in control and history soils was weaker than (i.e., $\mathrm{r}^{2}=$ 484 0.12, Fig. 6b) found in other studies (Keddy et al., 1994; Keddy et al., 2002; Wang et al., 2010). 485 Observing such context dependency in the competitive effect of $A$. petiolata was not unique to our study. For example, Smith \& Reynolds (2014) found that A. petiolata could suppress other species under high light conditions, but had much weaker effects in the shade. Our findings suggest the ability of competitor species to either resist suppression by, or suppress, $A$. petiolata cannot be confidently predicted from one ecological context to another. species in a community upon initial invasion via a relatively strong competitive ability. However, its competitive ability is weakened, rather than strengthened, by conspecific soil history effects. Like previous studies, we observed that soil with a history of A. petiolata reduces the ability of mycorrhizal fungi to colonize the roots of competitor species. However, this negative novel weapons effect on mycorrhizal plant species did not appear overcome the negative history effects of soil nutrient depletion on A. petiolata. These findings suggest that the inhibitory potential of $A$. petiolata on competitor species via mycorrhizal suppression may not be as strong as previously suggested. In addition, because longer term effects of $A$. petiolata 499 invasion include an overall increase in plant available soil nitrogen and phosphorus (Rodgers et al., 2008b), mycorrhizal suppression is unlikely to be a strong mechanism of competition in the 
501 years following invasion. This is because the effect of losing the fungal symbiont approaches

502 neutrality when mycorrhizal plants are grown with supplemental nutrients (Hoeksema et al., 503 2010; Johnson 2010). The potential for weak mycorrhizal suppression effects suggests that 504 eradication or control measures based on minimizing novel biochemical weapons effects in $A$. 505 petiolata may be less successful than other approaches. As suggested by other studies, reducing 506 propagule pressure by removal of flowering individuals (Herold et al., 2011; Phillips-Mao et al., 507 2014) and suppressing browsing by deer (Kalisz et al., 2014) could be more effective strategies 508 to counteract the invasion of A. petiolata in North America.

509

510 Acknowledgements

511 We thank A. Benoit, E. Bothwell, C.M. Caruso, E. Pacey, P. Rekret, R. Rivkin and three

512 anonymous reviewers for comments on the manuscript. N. Sokol and A.M. Benscoter assisted

513 with various phases of the project. 
514

515

516

517

518

519

520

521

522

523

524

525

526

527

528

529

530

531

532

533

534

535

536

537 538

\section{References}

Aerts R, Boot RGA, van der Aart PJM. 1991. The relation between above- and belowground biomass allocation patterns and competitive ability. Oecologia 87:551-559.

Barto EK, Antunes PM, Stinson K, Koch AM, Klironomos JN, Cipollini D. 2011. Differences in arbuscular mycorrhizal fungi communities associated with sugar maple seedlings in and outside of invaded A. petiolata forest patches. Biological Invasions 13:1627-1639.

Barto EK, Cipollini D. 2009. Half-lives and field soil concentrations of Alliaria petiolata secondary metabolites. Chemosphere 76:71-75.

Bever JD, Dickie IA, Facelli E, Facelli JM, Klironomos J, Moora M, Rillig MC, Stock M. Tibbett WD, Zobel M. 2010. Rooting theories of plant community ecology in microbial interactions. Trends in Ecology \& Evolution 25:468-478.

Biswas SR, Kotanen, PM, Kambo D, Wagner HH. 2015. Context-dependent patterns, determinants and demographic consequences of herbivory in an invasive species. Biological Invasions 17:165-178.

Blossey B, Notzold R. 1995. Evolution of increased competitive ability: a hypothesis. Journal of Ecology 83:887-889.

Brundrett MC, Piche Y, Peterson RL. 1984. A new method for observing the morphology of vesicular-arbuscular mycorrhizae. Canadian Journal of Botany 62:2128-2134.

Brundrett MC. 2009. Mycorrhizal associations and other means of nutrition of vascular plants: understanding the global diversity of host plants by resolving conflicting information and developing reliable means of diagnosis. Plant and Soil 320:37-77.

Callaway RM, Ridenour WM. 2004. Novel weapons: invasive success and the evolution of increased competitive ability. Frontiers in Ecology and the Environment 2:436-443.

Callaway RM, Thelen GC, Rodriguez A, Holben WE. 2004. Soil biota and exotic plant invasion. Nature 427:731-733. 
539 Callaway RM, Cipollini D, Barto K, Thelen GC, Hallett SG, Prati D, Stinson K, Klironomos J.

540 2008. Novel weapons: invasive plant suppresses fungal mutualists in America but not its $541 \quad$ native Europe. Ecology 89:1043-1055.

542 Catford JA, Jansson R, Nilsson C. 2009. Reducing redundancy in invasion ecology by

543 integrating hypotheses into a single theoretical framework. Diversity and Distributions, $544 \quad 15: 22-40$.

545 Colautti RI, Grigorovich IA, MacIsaac HJ. 2006. Propagule pressure: a null model for biological 546 invasions. Biological Invasions 8:1023-1037.

547 Cantor A, Hale A, Aaron J, Traw BM, Kalisz S. 2011. Low allelochemical concentrations 548 detected in A. petiolata-invaded soils inhibit fungal growth and AMF germination. 549 Biological Invasions 13:3015-3025.

550 Casper BB, Jackson RB. 1997. Plant competition underground. Annual Review of Ecology \& $551 \quad$ Systematics 28:545-570.

552 Cavers PB, Heagy MI, Kokron RF. 1979. The biology of Canadian weeds. 35. Alliaria petiolata 553 (M. Bieb.) Cavara and Grande. Canadian Journal of Plant Science 59:217-229.

554 Cipollini D, Mbagwu J, Barto K, Hillstrom C, Enright S. 2005. Expression of constitutive and 555 inducible chemical defenses in native and invasive populations of Alliaria petiolata. $556 \quad$ Journal of Chemical Ecology 31:1255-1267.

557 Cipollini D, Stevenson R, Cipollini K. 2008. Contrasting effects of allelochemicals from two 558 invasive plants on the performance of a nonmycorrhizal plant. International Journal of $559 \quad$ Plant Sciences 169:371-375.

560 Craine JM, Froehle J, Tilman DG, Wedin DA, Chapin III FS. 2001. The relationships among 561 root and leaf traits of 76 grassland species and relative abundance along fertility and 562 disturbance gradients. Oikos 93:274-285.

563 Davies TJ, Barraclough TG, Chase MW, Soltis PS, Soltis DE, Savolainen V. 2004. Darwin's 564 abominable mystery: insights from a supertree of the angiosperms. Proceedings of the 565 National Academy of Sciences of the United States of America 101:1904-1909. 
566 Davis MA, Colehour A, Daney J, Foster E, Macmillen C, Merrill E, O’Neill J, Pearson M,

567 Whitney M, Anderson MD, Dosch JJ. 2012. The population dynamics and ecological

568 effects of garlic mustard, Alliaria petiolata, in a Minnesota oak woodland. American

$569 \quad$ Midland Naturalist 168:364-374.

570 Dietz H, Edwards PJ. 2006. Recognition that causal processes change during plant invasion helps 571 explain conflicts in evidence. Ecology 87:1359-1367.

572 Engelhardt MJ, Anderson RC. 2011. Phenological niche separation of an invasive species 573 Alliaria petiolata. Journal of the Torrey Botanical Society 138:418-433.

574 Funk JL, Cleland EE, Suding KN, Zavaleta ES. 2008. Restoration through re-assembly: plant $575 \quad$ traits and invasion resistance. Trends in Ecology and Evolution 23:695-703.

576 Gaudet CL, Keddy PA. 1988. A comparative approach to predicting competitive ability from $577 \quad$ plant traits. Nature 34:242-243.

578 Goldberg DE. 1996. Competitive ability: definitions, contingency and correlated traits.

579 Philosophical Transactions of the Royal Society B: Biological Sciences 351:1377-1385.

580 Goldberg DE, Landa K. 1991. Competitive effect and response: hierarchies and correlated traits 581 in the early stages of competition. Journal of Ecology 79:1013-1030.

582 Grime JP. 1977. Evidence for the existence of three primary strategies in plants and its relevance 583 to ecological theory. American Naturalist 111:1169-1194.

584 Gurevitch J, Fox GA, Wardle GM, Inderjit S, Taub D. 2011. Emergent insights from the

585 synthesis of conceptual frameworks for biological invasions. Ecology Letters 14:407-418.

586 Hale AN, Kalisz S. 2012. Perspectives on allelopathic disruption of plant mutualisms: a 587 framework for individual-and population-level fitness consequences. Plant Ecology 213: $588 \quad 1991-2006$.

589 Herold J, Anderson MR, Bauer JT, Borowicz V, Anderson RC. 2011. Comparison of the effect 590 of early and late removal of second-year garlic mustard (Alliaria petiolata) on first-year 591 plants and deciduous forest spring and summer dominant herbaceous groundlayer species in central Illinois, USA. Ecological Restoration 29:225-233. 
593 Hoeksema JD, Chaudhary VB, Gehring CA, Johnson NC, Karst J, Koide RT, Pringle A,

594 Zabinski C, Bever JD, Moore JC, Wilson GWT, Klironomos JN, Umbanhowar J. 2010. A

595 meta-analysis of context-dependency in plant response to inoculation with mycorrhizal 596 fungi. Ecology Letters 13:394-407.

597 Johnson NC. 2010. Resource stoichiometry elucidates the structure and function of arbuscular 598 mycorrhizas across scales. New Phytologist 185: 631-647.

599 Kalisz S, Spigler RB, Horvitz CC. 2014. In a long-term experimental demography study, 600 excluding ungulates reversed invader's explosive population growth rate and restored 601 602 603 604 605 606 607 natives. Proceedings of the National Academy of Sciences of the United States of America $111: 4501-4506$.

Keddy PA, Twolan-Strutt L, Wisheu IC. 1994. Competitive effect and response rankings in 20 wetland plants: Are they consistent across three environments? Journal of Ecology 82:635-643.

Keddy PA, Neilsen K, Weiher E, Lawson R. 2002. Relative competitive performance of 63 species of terrestrial herbaceous plants. Journal of Vegetation Science 13:5-16.

Knight TM, Dunn JL, Smith LA, Davis J, Kalisz S. 2009. Deer facilitate invasive plant success in a Pennsylvania forest understory. Natural Areas Journal 29: 110-116.

Lamb EG, Shore BH, Cahill JF. 2007. Water and nitrogen addition differentially impact plant competition in a native rough fescue grassland. Plant Ecology 192:21-33.

Lankau RA, Nuzzo V, Spyreas G, Davis AS. 2009. Evolutionary limits ameliorate negative impact of an invasive plant. Proceedings of the National Academy of Sciences of the United States of America 106:15362-15367.

Lankau RA. 2010. Soil microbial communities alter allelopathic competition between Alliaria petiolata and a native species. Biological Invasions 12:2059-2068.

Lankau RA. 2011. Resistance and recovery of soil microbial communities in the face of Alliaria petiolata invasion. New Phytologist 189:536-548. 
619 Lau JA, Schultheis EH. 2015. When two invasion hypotheses are better than one. New $620 \quad$ Phytologist 205: 958-960.

621 Leicht-Young SA, Pavlovic NB, Adams JV. 2012. Competitive interactions of garlic mustard 622 (Alliaria petiolata) and damesrocket (Hesperis matronalis). Invasive Plant Science and 623 Management 5:27-36.

624 Mack RN, Simberloff D, Lonsdale WM, Evans H, Clout M, Bazzaz FA. 2000. Biotic invasions: causes, epidemiology, global consequences, and control. Ecological Applications 10:689711

627

628

629

630

Martins EP, Hansen TF. 1997. Phylogenies and the comparative method: a general approach to incorporating phylogenetic information into the analysis of inter-specific data. American Naturalist 149:646-667.

Maxwell K, Johnson GN. 2000. Chlorophyll fluorescence - a practical guide. Journal of Experimental Botany 51:659-668.

McCarthy BC, Hanson SL. 1998. An assessment of the allelopathic potential of the invasive weed Alliaria petiolata (Brassicaceae). Castanea 63:68-73.

McGonigle TP, Miller MH, Evans DG, Fairchild GL, Swan JA. 1990. A new method which gives an objective measure of colonization of roots by vesicular-arbuscular mycorrhizal fungi. New Phytologist 115:495-501.

Meekins JF, McCarthy BC. 1999. Competitive ability of Alliaria petiolata (Garlic Mustard, Brassicaceae), an invasive, nonindigenous forest herb. International Journal of Plant Sciences 160:743-752.

Meekins JF, McCarthy BC. 2002. Effect of population density on the demography of an invasive plant, Alliaria petiolata, (Brassicaceae) population in a Southeastern Ohio forest. American Midland Naturalist 147:256-278.

Orme D, Freckleton R, Thomas G, Petzoldt T, Fritz S, Isaac N, Pearse W. 2013. Caper: Comparative analyses of phylogenetics and evolution in R. R package version 0.5.2. http://CRAN.R-project.org/package=caper 
646 Pagel M. 1999. Inferring the historical patterns of biological evolution. Nature 401:877-884.

647 Parker IM, Rodriguez J, Loik ME. 2003. An evolutionary approach to understanding the biology 648 of invasions: local adaptation and general-purpose genotypes in the weed Verbascum 649 thapsus. Conservation Biology 17:59-72.

650 Phillips-Mao L, Larson DL, Jordan NR. 2014. Effects of native herbs and light on garlic mustard 651 (Alliaria petiolata) invasion. Invasive Plant Science and Management 7:257-268.

652 Pimental D, Lach L, Zuniga R, Morrison D. 2000. Environmental and economic costs of 653 nonindigenous species in the United States. Bioscience 5:53-65.

654 Prati D, Bossdorf O. 2004. Allelopathic inhibition of germination by Alliaria petiolata 655 (Brassicaceae). American Journal of Botany 91:285-288.

656 R Core Team 2014. R: A language and environment for statistical computing. R Foundation for 657 Statistical Computing, Vienna, Austria. URL http://www.R-project.org/.

658 Roberts KJ, Anderson RC. 2001. Effects of Garlic Mustard [Alliaria petiolata (Beib. Cavara \& 659 Grande)] extracts on plants and arbuscular mycorrhizal (AM) fungi. American Midland $660 \quad$ Naturalist $146: 146-152$

661 Rodgers VL, Stinson KA, Finzi AC. 2008a. Ready or not, Garlic Mustard is moving in: Alliaria 662 663 664 petiolata as a member of eastern North American forests. Bioscience 58:426-436.

Rodgers VL, Wolfe BE, Werden LK, Finzi AC. 2008b. The invasive species Alliaria petiolata (Garlic Mustard) increases soil nutrient availability in northern hardwood-conifer forests. Oecologia 157:455-471.

Rosch H, Van Rooyen MV, Theron GK. 1997. Predicting competitive interactions between pioneer plant species by using plant traits. Journal of Vegetation Science 4:489-494.

Smith LM, Reynolds HL. 2014. Light, allelopathy, and post-mortem invasive impact on native forest understory species. Biological Invasions 16:1131-1144. disrupting belowground mutualisms. PLoS Biology 4:e140. 
673 Stinson KA, Kaufman SR, Durbin LM, Lowenstein F. 2007. Responses of a New England forest 674 community to increasing levels of invasion by garlic mustard (Alliaria petiolata). $675 \quad$ Northeastern Naturalist 14:73-88.

676 Stinson KA, Seidler TG. 2014. Physiological constraints on the spread of Alliaria petiolata 677 populations in Massachusetts. Ecosphere 5:art96.

678 Tilman D. 1988. Plant strategies and the dynamics and structure of plant communities. 679 Princeton University Press, Princeton, New Jersey, USA.

680 Tilman D, Wedin D. 1991. Dynamics of nitrogen competition between successional grasses. $681 \quad$ Ecology 72:1038-1049.

682 Wang B, Qiu YL. 2006. Phylogenetic distribution and evolution of mycorrhizas in land plants. 683 Mycorrhiza 16:299-363.

684 Wang P, Stieglitz T, Zhou DW, Cahill JF. 2010. Are competitive effect and response two sides 685 of the same coin, or fundamentally different? Functional Ecology 24:196-207.

686 Wardle DA, Barker GM, Bonner KI, Nicholson KS. 1998. Can comparative approaches based on 687 plant ecophysiological traits predict the nature of biotic interactions and individual plant 688 species effects in ecosystems? Journal of Ecology 86:405-420.

689 690

Webb CO, Ackerly DD, Kembel SW. 2008. Phylocom: software for the analysis of phylogenetic community structure and trait evolution. Bioinformatics 24:2098-2100.

691 692

693

Wolfe BE, Rodgers VL, Stinson KA, Pringle A. 2008. The invasive plant Alliaria petiolata (Garlic Mustard) inhibits ectomycorrhizal fungi in it introduced range. Journal of Ecology 96:777-783.

695

696

697

Zheng Y-L, Feng Y-L, Zhang L-K, Callaway RM, Valiente-Banuet A, Luo D-Q, Liao ZY, Barclay GF, Silva-Pereyra C. 2015. Integrating novel chemical weapons and evolutionarily increased competitive ability in success of a tropical invader. $\mathrm{New}$ Phytologist 205:1350-1359. 
698 Figure Legends

699 Figure 1. Biomass of competitor species in response to competition with $A$. petiolata in control 700 (A) or soil with a history of $A$. petiolata (B). Biomass within each growth form are shown in the 701 insets. Black bars indicate plants grown alone and grey bars indicate plants grown in competition

702 with $A$. petiolata. Statistically significant differences were determined using planned orthogonal 703 1-df contrasts, and are indicated with an asterisk.

704

705 Figure 2. Biomass of $A$. petiolata alone or in response to competition with other species in 706 control (A) or soil with a history of $A$. petiolata (B). Biomass of $A$. petiolata alone versus in 707 competition with members of different growth forms are shown in the insets. Statistically 708 significant differences were determined using planned orthogonal 1-df contrasts, and are 709 indicated with an asterisk.

710

711 Figure 3. The log response ratio of plant biomass without competition in A. petiolata history

712 relative to control soil. Statistically significant differences between soil treatments were 713 determined using planned orthogonal 1-df contrasts, and are indicated with an asterisk.

715 Figure 4. The effect of soil history with $A$. petiolata on the colonization of roots by arbuscular 716 mycorrhizal (AM) hyphae (A) AM arbuscules (B), and vesicles (C). Statistically significant 717 differences between soil treatments are indicated with an asterisk.

718

719 Figure 5. The effect of growth form and exposure to either control or A. petiolata soil history on 720 quantum yield of PSII at weeks 5 and 9 (A), leaf chlorophyll concentration at weeks 5 and 9 (B) 721 and plant height at week 5 (C). The effect of growth form on root diameter (D) and specific root 722 length (E). Different letters above bars, when present, represent statistically significant 723 differences $(P<0.05)$ among groups within each treatment, as determined by a comparison of 724 95\% confidence limits among groups. 
726 Figure 6. Relationships between competitive response (A) or competitive effect (B) across 727 control and A. petiolata history soils. 


\section{1}

Figure 1

Figure 1. Biomass of competitor species in response to competition with A. petiolata in control (A) or soil with a history of A. petiolata (B). Biomass within each growth form are shown in the insets. Black bars indicate plants grown alone and grey bars indicate plants grown in competition with $A$. petiolata. Statistically significant differences were determined using planned orthogonal 1-df contrasts, and are indicated with an asterisk. 

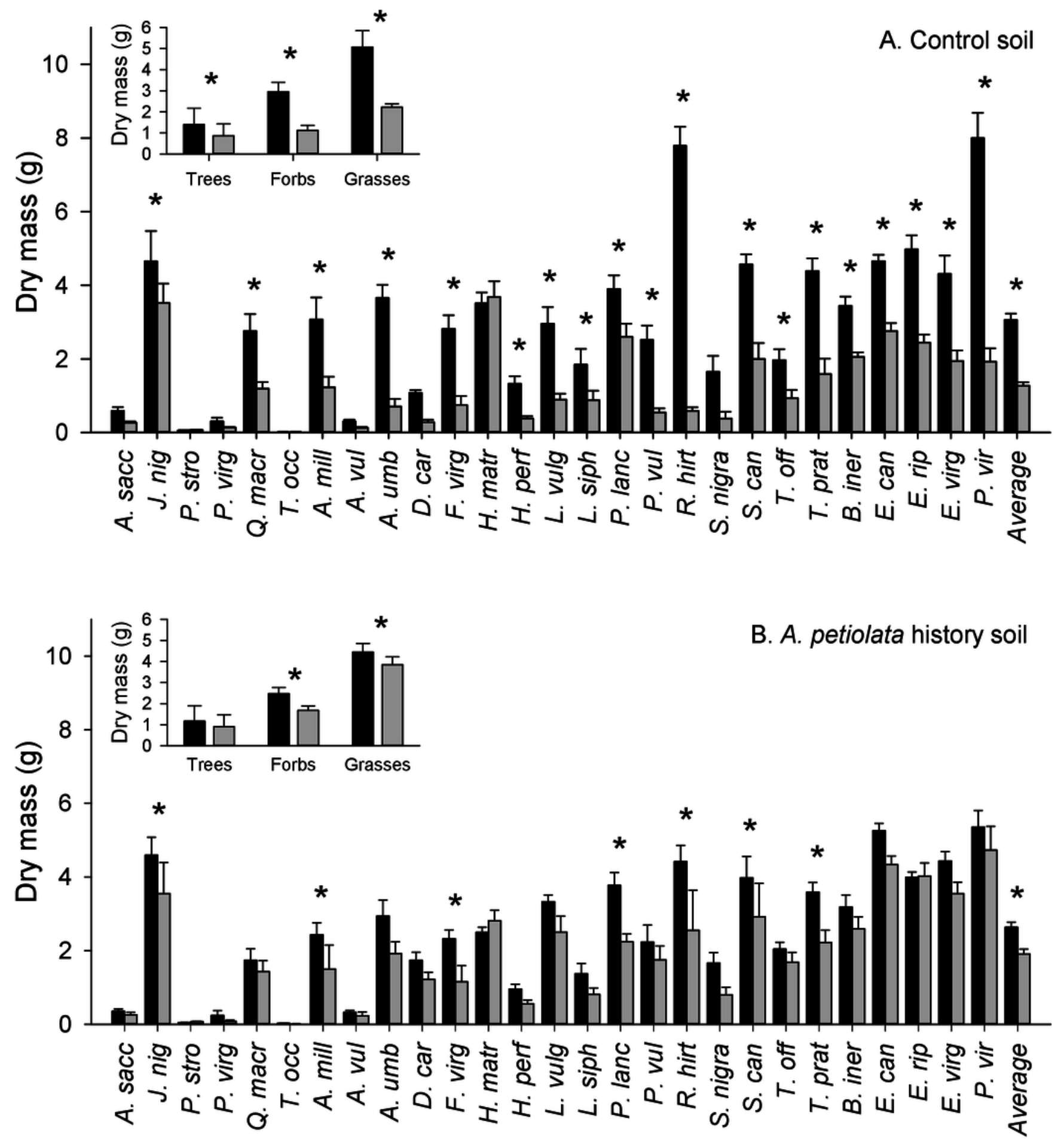
2

Figure 2

Figure 2. Biomass of $A$. petiolata alone or in response to competition with other species in control (A) or soil with a history of $A$. petiolata (B). Biomass of $A$. petiolata alone versus in competition with members of different growth forms are shown in the insets. Statistically significant differences were determined using planned orthogonal 1-df contrasts, and are indicated with an asterisk. 

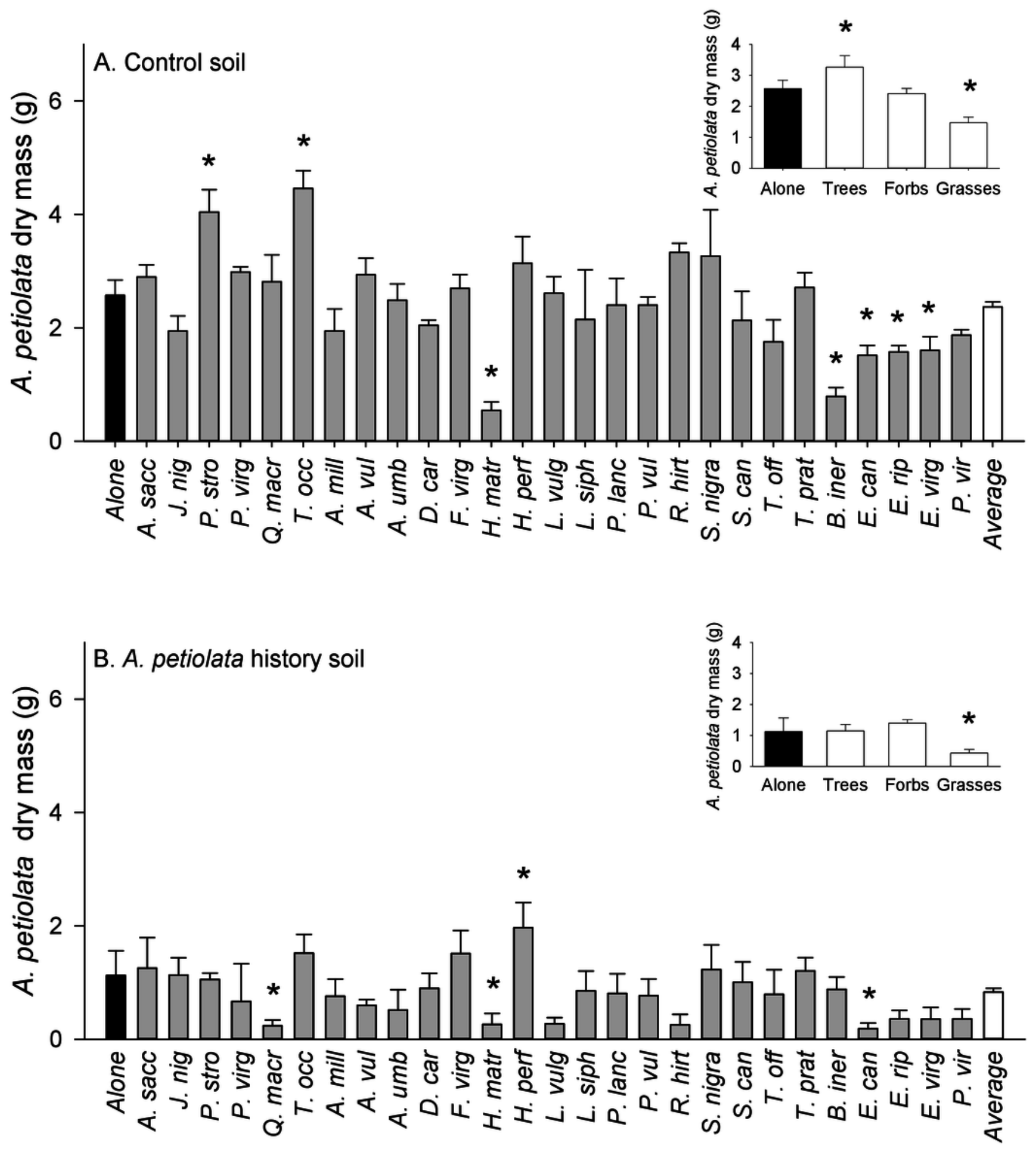
3

Figure 3

Figure 3. The log response ratio of plant biomass without competition in A. petiolata history relative to control soil. Statistically significant differences between soil treatments were determined using planned orthogonal 1-df contrasts, and are indicated with an asterisk. 


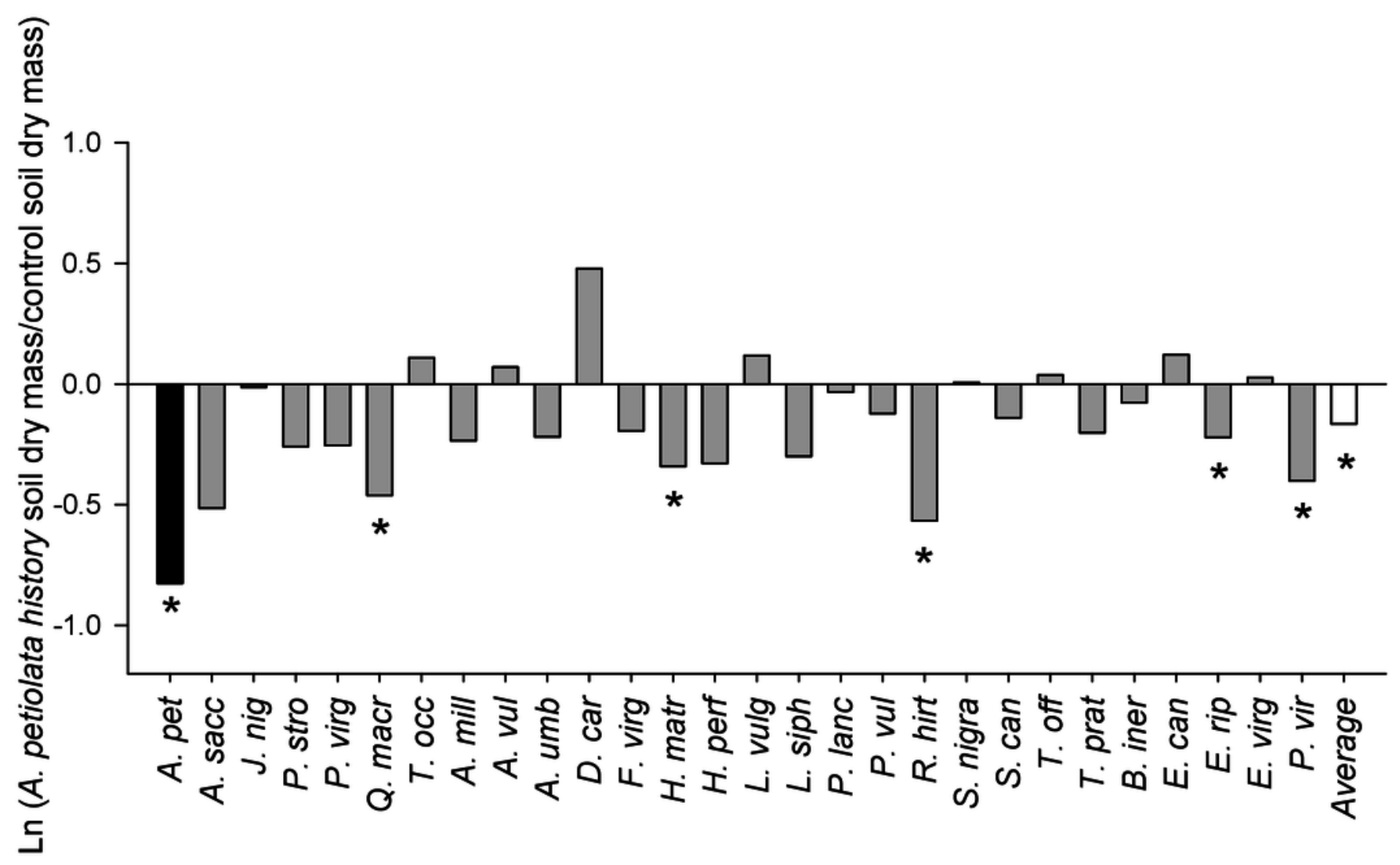


4

Figure 4

Figure 4. The effect of soil history with $A$. petiolata on the colonization of roots by arbuscular mycorrhizal (AM) hyphae (A) AM arbuscules (B), and vesicles (C). Statistically significant differences between soil treatments are indicated with an asterisk. 

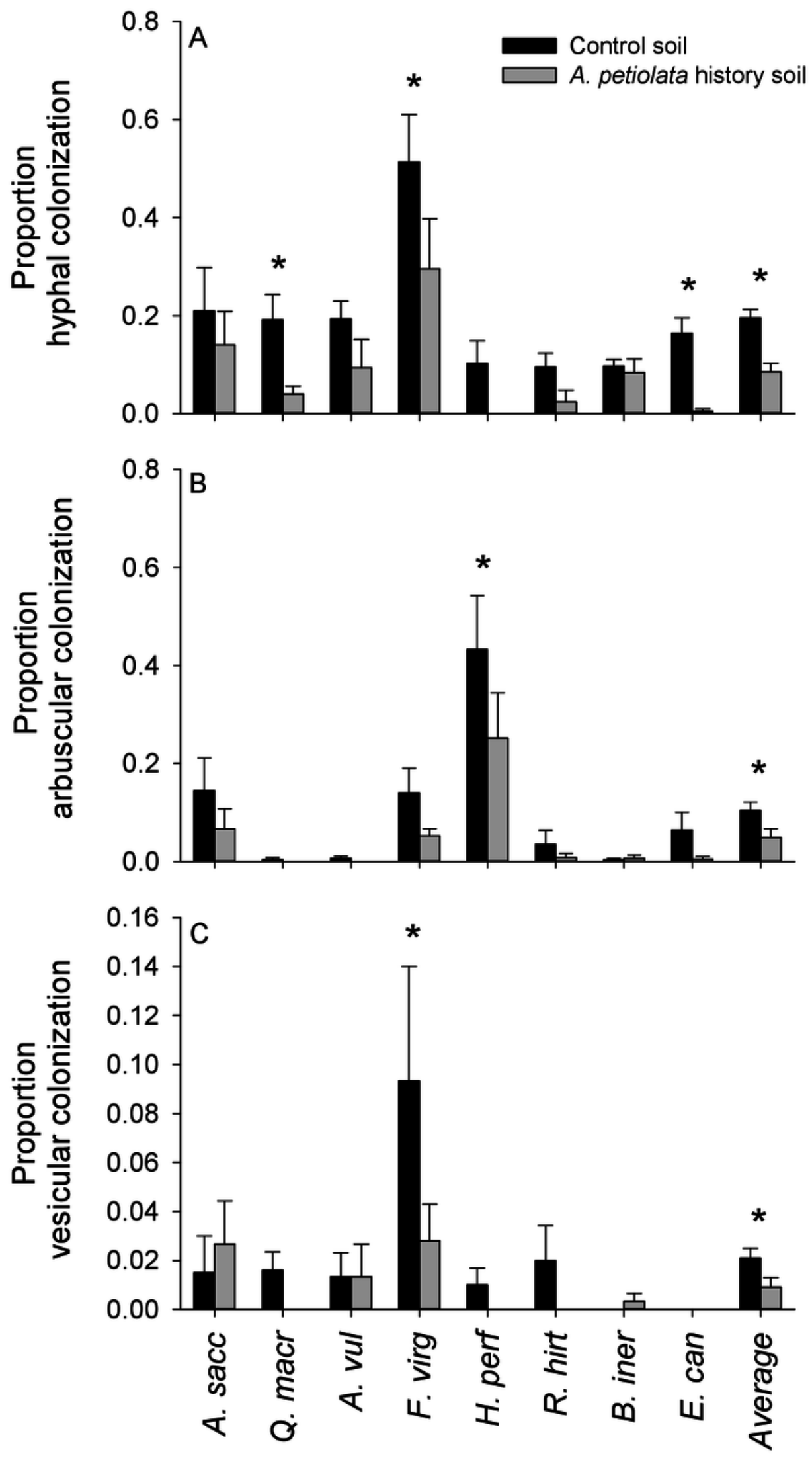


\section{5}

Figure 5

Figure 5. The effect of growth form and exposure to either control or A. petiolata soil history on quantum yield of PSII at weeks 5 and 9 (A), leaf chlorophyll concentration at weeks 5 and 9 (B) and plant height at week 5 (C). The effect of growth form on root diameter (D) and specific root length (E). Different letters above bars, when present, represent statistically significant differences $(P<0.05)$ among groups within each treatment, as determined by a comparison of $95 \%$ confidence limits among groups.
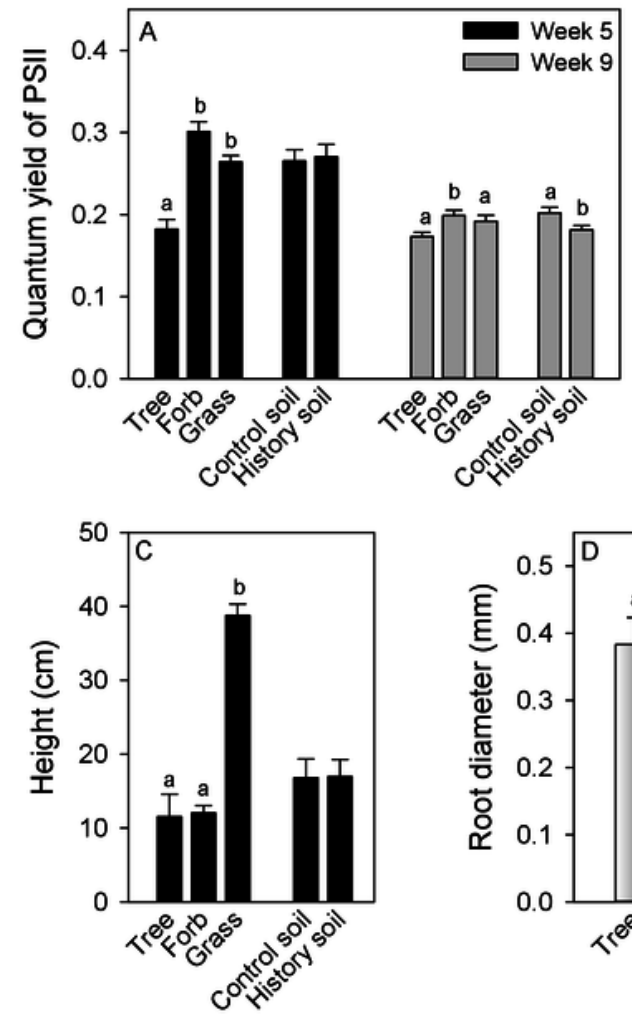
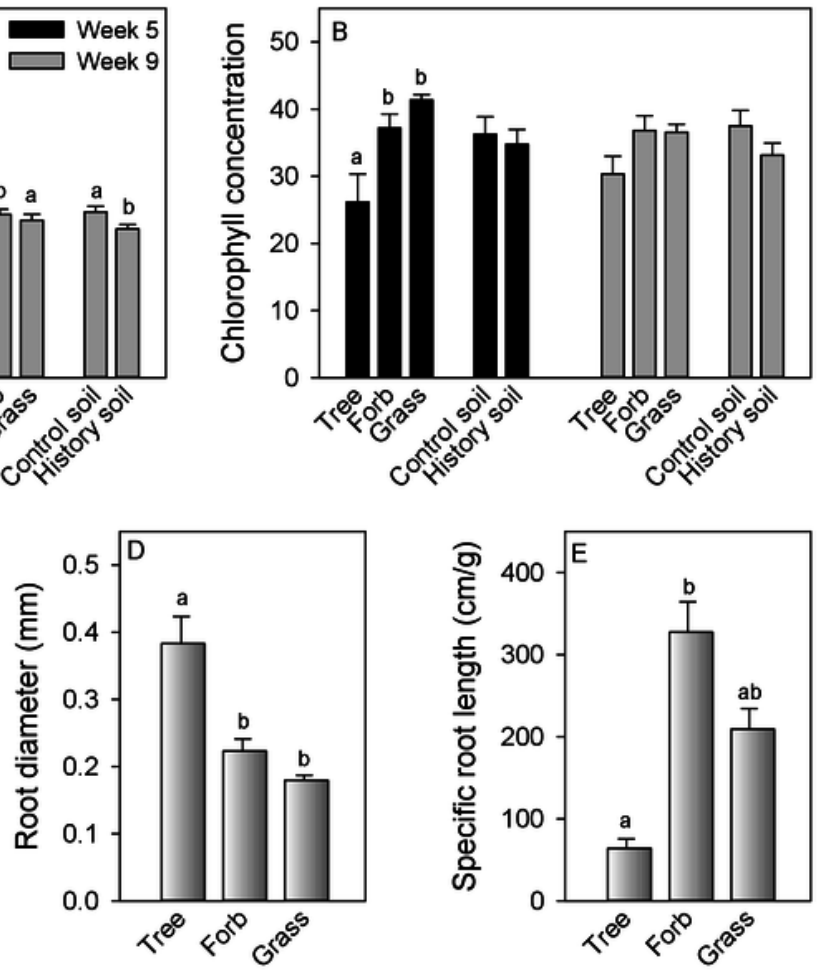


\section{6}

Figure 6

Figure 6. Relationships between competitive response (A) or competitive effect (B) across control and $A$. petiolata history soils. 

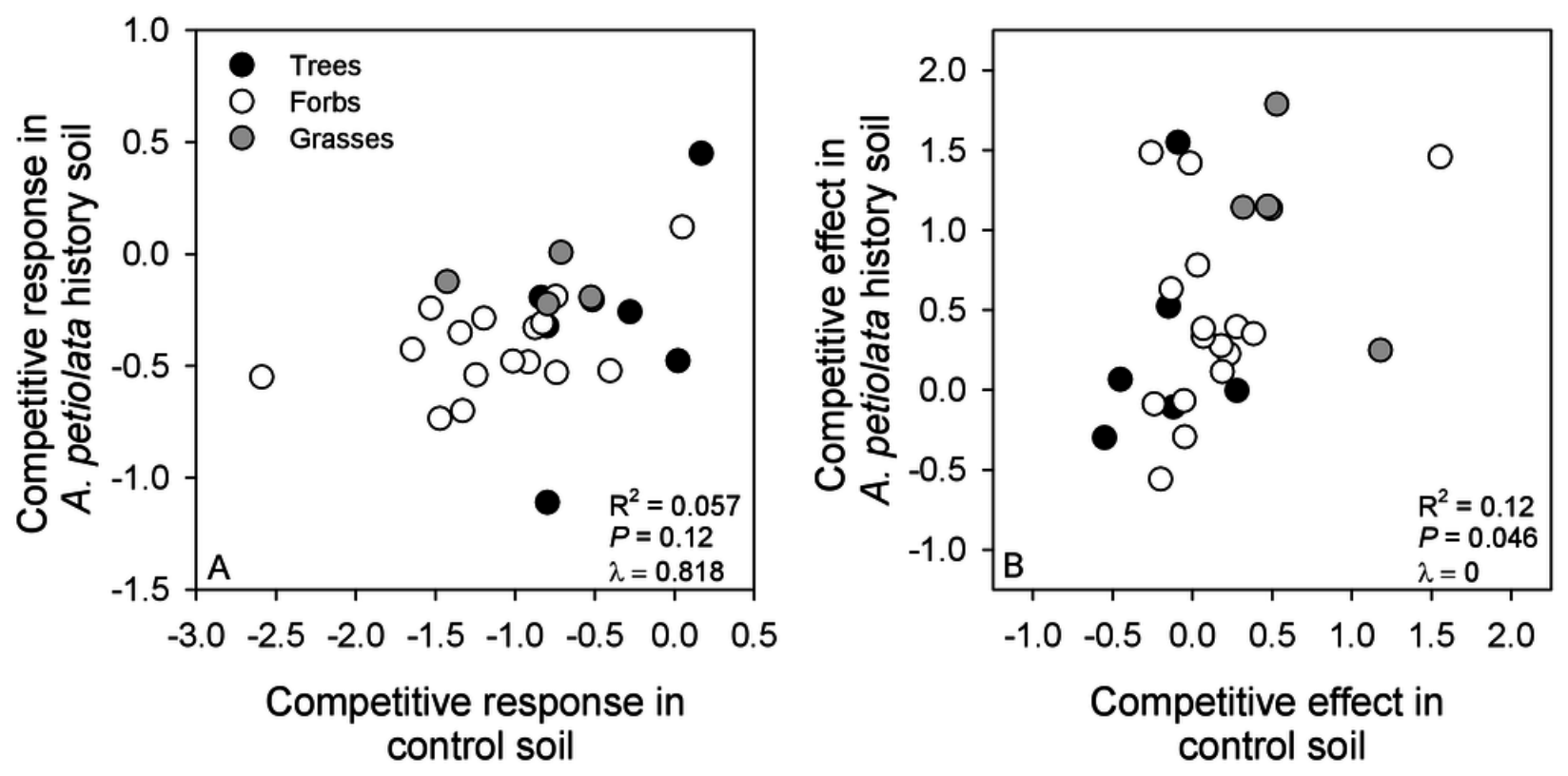


\section{Table $\mathbf{1}_{\text {(on next page) }}$}

Table 1

Table 1. List of competitor species used in the study, along with information on their plant family affiliation, growth form, status in North America (18 native, 9 introduced), and whether plants are arbuscular mycorrhizal (AM), ecto-mycorrhizal (ECM), or ambiguous (both mycorrhizal and non-mycorrhizal states reported in the literature). Mycorrhizal state was determined from Wang \& Qiu (2006). Seeds were obtained from ${ }^{A} A$ corus Restoration, ${ }^{B}$ Angelgrove Seed Company, COntario Tree Seed Facility ${ }^{D}$ Richters Herbs, or field collections from the EUniversity of Guelph Arboretum. 
Table 1. List of competitor species used in the study, along with information on their plant family affiliation, growth form, status in

3 North America (18 native, 9 introduced), and whether plants are arbuscular mycorrhizal (AM), ecto-mycorrhizal (ECM), or

4 ambiguous (both mycorrhizal and non-mycorrhizal states reported in the literature). Mycorrhizal state was determined from Wang \&

5 Qiu (2006). Seeds were obtained from AAcorus Restoration, ${ }^{B}$ Angelgrove Seed Company, ${ }^{C}$ Ontario Tree Seed Facility ${ }^{\mathrm{D}}$ Richters

6 Herbs, or field collections from the EUniversity of Guelph Arboretum.

7

\begin{tabular}{|c|c|c|c|c|}
\hline Latin name & Family & Growth Form & Status & Mycorrhizal State \\
\hline${ }^{1}$ Acer saccharum L. & Aceraceae & Tree & Native $^{\mathrm{C}}$ & AM \\
\hline${ }^{1}$ Juglans nigra L. & Juglandaceae & Tree & Native $^{\mathrm{C}}$ & AM \\
\hline${ }^{2}$ Pinus strobus L. & Pinaceae & Tree & Native $^{\mathrm{C}}$ & ECM \\
\hline${ }^{1}$ Prunus virginiana $\mathrm{L}$. & Rosaceae & Tree & Native $^{\mathrm{C}}$ & AM \\
\hline${ }^{2}$ Quercus macrocarpa Michx. & Fagaceae & Tree & Native $^{\mathrm{C}}$ & ECM \\
\hline${ }^{1}$ Thuja occidentalis L. & Cupressaceae & Tree & Native $^{\mathrm{C}}$ & AM \\
\hline${ }^{1}$ Achillea millefolium L. & Asteraceae & Perennial Forb & Native $^{\mathrm{D}}$ & $\mathrm{AM}$ \\
\hline${ }^{1}$ Aquilegia vulgaris L. & Ranunculaceae & Perennial Forb & Introduced ${ }^{\mathrm{D}}$ & $\mathrm{AM}$ \\
\hline${ }^{1}$ Aster umbellatus Miller & Asteraceae & Perennial Forb & Native $^{\mathrm{D}}$ & $\mathrm{AM}$ \\
\hline${ }^{1}$ Daucus carota L. & Apiaceae & Biennial Forb & Introduced $^{\mathrm{E}}$ & $\mathrm{AM}$ \\
\hline${ }^{1}$ Fragaria virginiana Miller. & Rosaceae & Perennial Forb & Native $^{B}$ & $\mathrm{AM}$ \\
\hline${ }^{3}$ Hesperis matronalis L. & Brassicaceae & Biennial Forb & Introduced $\mathrm{A}^{\mathrm{A}}$ & Ambiguous \\
\hline${ }^{1}$ Hypericum perforatum L. & Clusiaceae & Perennial Forb & Introduced ${ }^{\mathrm{A}}$ & $\mathrm{AM}$ \\
\hline${ }^{1}$ Leucanthemum vulgare Lam. & Asteraceae & Perennial Forb & Introduced $\mathrm{A}^{\mathrm{A}}$ & $\mathrm{AM}$ \\
\hline${ }^{1}$ Lobelia siphilitica $\mathrm{L}$. & Campanulaceae & Perennial Forb & Native $^{\mathrm{A}}$ & $\mathrm{AM}$ \\
\hline${ }^{1}$ Plantago lanceolata $\mathrm{L}$. & Plantaginaceae & Perennial Forb & Introduced $\mathrm{d}^{\mathrm{D}}$ & $\mathrm{AM}$ \\
\hline${ }^{1}$ Prunella vulgaris L. & Lamiaceae & Perennial Forb & Native $^{B}$ & $\mathrm{AM}$ \\
\hline${ }^{1}$ Rudbeckia hirta L. & Asteraceae & Perennial Forb & Native $^{B}$ & AM \\
\hline${ }^{3}$ Sambucus nigra spp. canadensis L. & Caprifoliaceae & Perennial Forb & Native $^{\mathrm{A}}$ & Ambiguous \\
\hline${ }^{1}$ Solidago canadensis L. & Asteraceae & Perennial Forb & Native $^{\mathrm{E}}$ & $\mathrm{AM}$ \\
\hline
\end{tabular}




\begin{tabular}{llll}
\hline${ }^{1}$ Taraxacum officinale F.H. Wigg. & Asteraceae & Perennial Forb & Introduced $^{\mathrm{B}}$ \\
${ }^{1}$ Trifolium pratense L. & Fabaceae & Biennial Forb & Introduced $^{\mathrm{E}}$ \\
${ }^{1}$ Bromus inermis Leyss. & Poaceae & Perennial Grass & Introduced $^{\mathrm{E}}$ \\
${ }^{1}$ Elymus canadensis L. & Poaceae & Perennial Grass & Native $^{\mathrm{B}}$ \\
${ }^{1}$ Elymus riparius Wiegand. & Poaceae & Perennial Grass & Native $^{\mathrm{B}}$ \\
${ }^{1}$ Elymus virginicus L. & Poaceae & Perennial Grass & Native $^{\mathrm{B}}$ \\
${ }^{1}$ Panicum virgatum L. & Poaceae & Perennial Grass & Native $^{\mathrm{A}}$ \\
\hline
\end{tabular}




\section{Table 2 (on next page)}

Table 2

Table 2. A three-way ANOVA table describing the effects of species identity, competition with A. petiolata, soil history and their interactions on dry mass of competitor species. 
1 Table 2. A three-way ANOVA table describing the effects of species identity, competition with A. petiolata, soil history and their 2 interactions on dry mass of competitor species.

3

\begin{tabular}{lccccc}
\hline Source & $\begin{array}{c}\text { Type III Sums } \\
\text { of Squares }\end{array}$ & df & Mean Square & $\boldsymbol{F}$ & $\boldsymbol{P}$ \\
\hline Species & 1141.51 & 26 & 43.90 & 66.78 & $5.29 \times 10^{-144}$ \\
Soil history & 1.41 & 1 & 1.41 & 2.14 & 0.144 \\
Competition & 209.97 & 1 & 209.97 & 319.38 & $1.57 \times 10^{-55}$ \\
Species * Soil history & 32.20 & 26 & 1.24 & 1.88 & 0.006 \\
Species * Competition & 141.18 & 26 & 5.43 & 8.26 & $1.76 \times 10^{-25}$ \\
Soil history* Competition & 45.14 & 1 & 45.14 & 68.65 & $1.10 \times 10^{-15}$ \\
Species * Soil history* Competition & 68.44 & 26 & 2.63 & 4.00 & $4.42 \times 10^{-10}$ \\
Error & 326.75 & 497 & 0.66 & & \\
\hline
\end{tabular}

4 


\section{Table 3(on next page)}

Table 3

Table 3. A two-way ANOVA table describing the effects of competitor species identity, soil history and their interaction on the dry mass of $A$. petiolata. 
2 Table 3. A two-way ANOVA table describing the effects of competitor species identity, soil history and their interaction on the dry 3 mass of $A$. petiolata.

4

\begin{tabular}{lccccc}
\hline Source & $\begin{array}{c}\text { Type III Sums } \\
\text { of Squares }\end{array}$ & df & $\begin{array}{c}\text { Mean } \\
\text { Square }\end{array}$ & $\boldsymbol{F}$ & $\boldsymbol{P}$ \\
\hline Species & 92.4 & 26 & 3.55 & 6.76 & $3.74 \times 10^{-17}$ \\
Soil history & 179.59 & 1 & 179.59 & 341.39 & $9.51 \times 10^{-48}$ \\
Species * Soil history & 40.37 & 26 & 1.55 & 2.95 & $7.30 \times 10^{-06}$ \\
Error & 124.15 & 236 & 0.53 & & \\
\hline
\end{tabular}

5 


\section{Table 4(on next page)}

Table 4

Table 4 Partial correlation coefficients $(\beta)$ indicating relationships between competitive response (CR) or competitive effect (CE) in control or history soil, and plant functional traits, including height at 5 weeks, quantum yield of PS II in the light [Y(II)] at 5 and 9 weeks, leaf chlorophyll content at 5 and 9 weeks, mean root diameter and specific root length (SRL). Because traits differed between trees, forbs and grasses, plant growth form was included as a covariate in the analysis, but only $\beta$ and significance values for traits are shown. The degree to which residuals from the multiple regression were correlated with phylogeny is indicated by $\lambda$. 
Table 4. Partial correlation coefficients $(\beta)$ indicating relationships between competitive response (CR) or competitive effect (CE) in control or history soil, and plant functional traits, including height at 5 weeks, quantum yield of PS II in the light [Y(II)] at 5 and 9 weeks, leaf chlorophyll content at 5 and 9 weeks, mean root diameter and specific root length (SRL). Because traits differed between trees, forbs and grasses, plant growth form was included as a covariate in the analysis, but only $\beta$ and significance values for traits are shown. The degree to which residuals from the multiple regression were correlated with phylogeny is indicated by $\lambda$.

\begin{tabular}{|c|c|c|c|c|c|c|c|}
\hline Dependent variable & Trait & $\boldsymbol{\beta}$ & $\boldsymbol{P}$ & Dependent variable & Trait & $\boldsymbol{\beta}$ & $P$ \\
\hline \multirow{5}{*}{$\begin{array}{l}\text { CR control soil } \\
\lambda=0\end{array}$} & Height@5 wks & -0.12 & 0.59 & \multirow{5}{*}{$\begin{array}{l}\text { CR history soil } \\
\lambda=1\end{array}$} & Height@5 wks & -0.09 & 0.70 \\
\hline & Y(II)@ 5 wks & 0.023 & 0.92 & & Y(II)@ 5 wks & 0.42 & 0.06 \\
\hline & Y(II)@9wks & 0.18 & 0.44 & & Y(II)@9wks & 0.082 & 0.72 \\
\hline & Chl@5 wks & -0.040 & 0.86 & & Chl@5 wks & 0.080 & 0.73 \\
\hline & Chl@9wks & 0.053 & 0.82 & & Chl@9wks & -0.16 & 0.49 \\
\hline \multirow{5}{*}{$\begin{array}{l}\text { CE control soil } \\
\lambda=0\end{array}$} & Height@5 wks & -0.02 & 0.93 & \multirow{5}{*}{$\begin{array}{l}\text { CE history soil } \\
\lambda=0\end{array}$} & Height@5 wks & 0.064 & 0.78 \\
\hline & Y(II)@ 5 wks & 0.27 & 0.24 & & Y(II)@ 9 wks & 0.063 & 0.79 \\
\hline & Y(II)@9wks & -0.11 & 0.64 & & Y(II)@9wks & 0.050 & 0.83 \\
\hline & Chl@ @ wks & 0.061 & 0.79 & & Chl@5 wks & -0.12 & 0.61 \\
\hline & Chl@9wks & 0.11 & 0.63 & & Chl@9wks & 0.25 & 0.27 \\
\hline \multirow{2}{*}{$\begin{array}{l}\text { CR control soil } \\
\lambda=0\end{array}$} & Root diameter & -0.23 & 0.28 & \multirow{2}{*}{$\begin{array}{l}\text { CR history soil } \\
\lambda=0.981\end{array}$} & \multirow{2}{*}{$\begin{array}{l}\text { Root diameter } \\
\text { SRL }\end{array}$} & -0.11 & 0.61 \\
\hline & SRL & 0.09 & 0.67 & & & -0.13 & 0.57 \\
\hline CE control soil & Root diameter & -0.35 & 0.11 & CE history soil & Root diameter & -0.22 & 0.32 \\
\hline$\lambda=1$ & SRL & -0.10 & 0.64 & $\lambda=0$ & SRL & -0.23 & 0.30 \\
\hline
\end{tabular}

